\title{
THE EFFECT OF SUPER-ABSORBENT POLYMER AND SOWING DEPTH ON GROWTH AND YIELD INDICES OF POTATO (SOLANUM TUBEROSUM L.) IN HAMEDAN PROVINCE, IRAN
}

\author{
SAlAVATI, S. ${ }^{1}-$ VALADABADI, S. A. ${ }^{1 *}-$ PARVIZI, K. H. ${ }^{2}-$ SAYFZADEH, S. $^{1}-$ HADIDI \\ MASOULEH, E. ${ }^{1}$ \\ ${ }^{I}$ Department of Agronomy, College of Agriculture, Takestan Branch, Islamic Azad University \\ Takestan, Iran \\ (phone: +98-81-3826-6448)
}

${ }^{2}$ Horticulture Crops Research Department, Hamedan Agricultural and Natural Resources

Research and Education Center, AREEO, Hamedan, Iran

(phone: +98-81-3437-3587)

*Corresponding author

e-mail:dr.valadabady@yahoo.com; phone:+98-28-3527-0130

(Received 24 $4^{\text {th }}$ Jul 2018; accepted $5^{\text {th }}$ Oct 2018)

\begin{abstract}
In order to evaluate the effect of using super-absorbent polymer (SAP) on quantitative yield and growth indices of potato in autumn sowing, an experiment was conducted in Hamedan city, Hamedan province, Iran during two crop years. The experiment was conducted as split split plot based on randomized complete block design (RCBD) with three replications. Treatments include sowing depth (10, 15, 20 and $25 \mathrm{~cm}$ ), potato cultivars (Sante, Fontane, and Agria) and SAP (non-application and application). The use of SAP in all three cultivars led to an increase in stem diameter, crop height and tuber yield and resulted in a decrease in the percentage of tuber dry weight. The results of growth indices showed that in all three cultivars, the use of SAP led to an increase in leaf area index (LAI), in leaf area duration (LAD) and in crop growth rate (CGR). The LAI and LAD increased with increasing depth and use of SAP. The highest LAI and LAD were obtained under conditions of using SAP at three depths. At all sowing depth, the use of SAP resulted in an increase in CGR relative to the non-use of SAP.
\end{abstract}

Keywords: Agria, Sante, superabsorbent polymer, tuber yield, Fontane

\section{Introduction}

Drought is one of the biggest challenges in the agricultural sector of Iran. Almost $90 \%$ of the regions in Iran are considered to have arid and semi-arid climates (Bannayan et al., 2010). In this respect, we must apply methods that can improve better water use efficiency (WUE) and do not damage the sustainable production of potato (Solanum tuberosum L.) as important crop in these regions (Parvizi and GhadamiFiroozabadi, 2015). Reports showed that drought stress induces a wide range of physiological and biochemical changes in crops (Garg et al., 2012; Maksup et al., 2014). In general, dehydration in crops increases cell volume, cell division, cell growth and crop dry weight, and reduces them relatives to non-stress conditions (Sirousmehr et al., 2014).

Potato is currently the fourth most important food crop in the world after wheat, rice, and corn (FAO, 2008). The area under potato cultivation in Iran in 2013 was 190,000 hectares and its yield in area under potato cultivation in Iran was reported as over $29,2623 \mathrm{~kg} / \mathrm{ha}$ in 2013 (FAO, 2013). Several studies indicated that potato is sensitive to drought stress in all growth stages, especially the tuber formation stage due to the shallow roots with limited expansion and its inability to absorb water from lower depths (Ayas, 2013; Shock et al., 2013). Increasing the use of this crop in the food industry in 
line with the growing world's population made the farmers and agricultural specialists to approach the production of this product to its genetic potential by eliminating nutrient deficiencies and managing the correct use of water and fertilizers (Haase et al., 2007).

In terms of total tuber yield, the early-season to mid-season cultivars of Marfona, Arinda, Fresco and Sante are superior to other cultivars. In general, the early-season to mid-season cultivars of Sante and Faresco and the late-season cultivars of Agria, Columbus, Timothy, Satina and Julianus are more suitable for potato cultivation and production in Hamedan Province (Parvizi, 2008).

The use of superabsorbent polymers (SAP) is one of the strategies to reduce the effect of drought stress especially in semi-arid regions of Iran. SAP are water-friendly gels which the water inside it is slowly evacuated and the soil remains moist for a long time after water absorption and drying the environment gradually (Ghooshchi, 2015). SAP in agriculture reduce the number of irrigation up to $50 \%$, increase the water and nutrition storage capacity of the soil for a long time, make the uniform use of water for crops, cause the faster and more favorable root growth, decrease the soil nutrient leaching, reduce the irrigation costs, increase the cationic exchange capacity of the soil, maximize the production potential of crop production, provide moisture in the upper layer of the soil, and increase the faster and more healthy growth of crops, especially in very hot and dry areas (Yazdani et al., 2007; He and Zhang, 2005). In a study, the use of SAP led to the increase of crop height, stem diameter, grain yield and biomass yield (Islam et al., 2011). In another study, the effect of organic and SAP on leaf chlorophyll index and their interaction effect on stomatal and nitrogen conductivity were statistically significant. In this study, the use of SAP increased the percentage of phosphorus in potato tubers (Rashidi et al., 2015).

Another method of management of potato yield increase is determining the appropriate sowing depth playing an essential role in forming the number of stolons and potato aerial stem and ultimately the final yield of potato (Ezekiel, 1992). The sowing depth determines the status and changes in the soil heat and moisture and is a criterion for soil resistance to the primary bud exit from the soil. Abducting the suitable sowing growth causes a delay in the rate of emergence or weakness of the seedlings (Acquaah, 2005). Several research results showed the significant effect of sowing depth on potato yield (Esehaghbeygi, 2010; Arab et al., 2011). Although in the autumn sowing, there will be a risk of frozen tubers under the soil if there is a severe cold weather but this possibility will decrease if the tubers are sown deeply. Thus, the autumn sowing of potato in temperate and semi-temperate regions is of great importance for some reasons such as reduced water consumption, higher sales prices, optimal utilization and maximum utilization of fall and winter precipitation resources and can be appropriate to change the pattern of sowing (Hassanpanah, 2016). The present study aimed at evaluating the effect of using moisture superabsorbent on growth and yield indices of autumn potato with different depths to reduce the adverse effects of drought stress.

\section{Materials and methods}

This experiment was carried out during two crop years of 2015-2016 and 2016-2017 at Ekbatan Research Station, Hamedan Agricultural and Natural Resources Research Center, Hamedan city, Hamedan province, (34 ${ }^{\circ} 88^{\prime}$ North, $48^{\circ} 53^{\prime}$ 'West and $1731 \mathrm{~m}$ above sea level) which is located in the west of Iran (Fig. 1). 


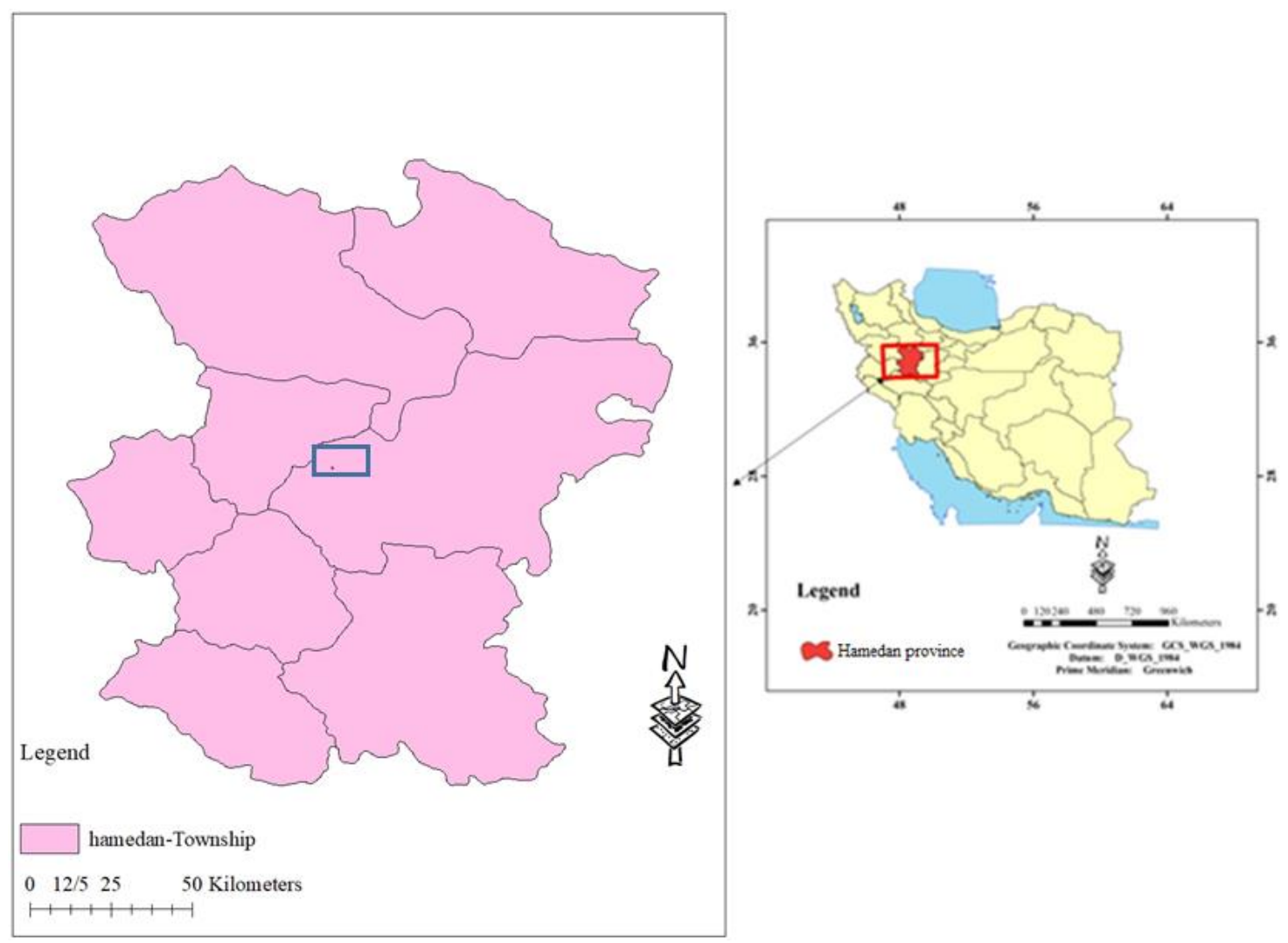

Figure 1. The location of the experiment area, Hamedan city, Hamedan province, Iran

The experiment was conducted as split plot based on randomized complete block design (RCBD) with three replications. The main factor included the sowing depth at four levels $(10,15,20$ and $25 \mathrm{~cm})$, the subplots included the potato cultivar at three levels (early-season Sante, mid-season Fontane, and late-season Agria) and the subsubplot included the use of SAP as $80 \mathrm{~kg} /$ ha and at two levels (without using (control) and using SAP). Before the cultivation, sampling was carried out with a depth of 0$30 \mathrm{~cm}$ to determine the physical and chemical characteristics of soil in the test site and the full specifications are presented in Table 1. Tillage was carried out in the autumn. After land levelling, a plot of $14 \mathrm{~m}^{2}$ was started. Each plot included 3 rows of planting at a distance of $75 \mathrm{~cm}$ and a length of $6 \mathrm{~m}$, the block spacing was one meter and the crop spacing in each row was $25 \mathrm{~cm}$.

Table 1. Experimental farm soil specification

\begin{tabular}{c|c|c|c|c|c|c}
\hline Soil depth & Soil texture & $\mathbf{p H}$ & $\mathbf{E C}$ & $\begin{array}{c}\text { Nitrogen } \\
\text { percentage }\end{array}$ & $\begin{array}{c}\text { Absorbable } \\
\text { phosphorus (mg/kg) }\end{array}$ & $\begin{array}{c}\text { Absorbable } \\
\text { potassium (mg/kg) }\end{array}$ \\
\hline $0-30$ & Clay loam & 7.8 & 1.8 & 0.35 & 4.8 & 386.3 \\
\hline
\end{tabular}

Fertilizer application was performed based on soil analysis. Accordingly, $250 \mathrm{~kg}$ of ammonium phosphate and $150 \mathrm{~kg}$ of potassium sulfate per hectare were used. Before sowing, the seed tubers were disinfected by Rural T. S fungicide $(52.5 \%$ wettable 
powder). The SAP was distributed to $80 \mathrm{~kg} / \mathrm{ha}$ at the time of sowing the tubers in cultivation grooves. Sowing the tubers was carried out on November 20th and the tubers were under the soil and in sleep throughout the winter. In the spring and before the buds leave the soil, the first turn of the weed control was carried out with paraquat (Gramaxone) herbicide (3 liters per hectare). Then, the weed control was carried out manually by observing the first weed and continued until the product was ripe. Irrigation was carried out as droplets and tapes. When the crop height reached 10-15 $\mathrm{cm}$, the cultivator and soil were carried out at the foot of the crops. During the grazing time, the complete fertilization of Humex micro fertilizer (at 3,000) was carried out in one turn while Urea fertilization was carried out as topdressing in two turns (mobbing and flowering stages). In flowering stage, the traits such as number of stems per crop, crop height and stem diameter were measured.

At the time of harvesting after random sampling from a square meter, the marginal effect was removed and the resulting tubers were weighed to obtain the tuber yield in kilograms per square meter. In order to calculate the percentage of tuber dry matter from each plot, three tubers were randomly weighed thoroughly after washing, then they were cut into thin chips and placed in an oven at $70^{\circ} \mathrm{C}$ for $48 \mathrm{~h}$. Then, they were weighed again and the percentage of tuber dry matter was calculated by dividing the dry weight of the tubers by their initial weight multiplied by 100 . For measurements of growth indices, $1 \mathrm{~m}^{2}$ of each plot were randomly selected from the central rows in plots. The remaining rows (except the border rows) were used for taking periodic plant samples. The sampling was done at 185, 192, 199 and 205 days after sowing. Then, the crops were dried in an oven at $75{ }^{\circ} \mathrm{C}$ for $48 \mathrm{~h}$ to be weighed. The rate of leaf area index ( $L A I)$, crop growth rate $(C G R)$ and leaf area duration $(L A D)$ were obtained from the Equations 1-3, respectively (Taiz and Zeiger, 2006):

$$
\begin{gathered}
L A I=\frac{L A_{1}+L A_{2}}{2} \times \frac{1}{G A} \\
C G R=\frac{W_{3}-W_{1}}{G A\left(t_{2}-t_{1}\right)} \\
L A D=\left(\frac{L A I_{1}+L A I_{2}}{2}\right)\left(t_{2}-t_{1}\right)
\end{gathered}
$$

where $L A_{2}+L A_{1}$ is total leaf area, $G A$ is ground area $W_{2}-W_{1}$ is dry weight changes, $t_{2}-$ $t_{1}$ is sampling time interval and $L A I_{1}+L A I_{2}$ is total leaf area at time interval of $t_{2}-t_{1}$.

The data obtained from the experiment were analysed by SAS statistical program (v.9.12) and the averages ere compared by Duncan's multiple range test at the 5\% level. The charts were drawn by Excel (2010) software.

\section{Results}

\section{The number of days up to $50 \%$ germination}

The results of compound analysis indicated the significant effect of year (Y), sowing depth (D), cultivar (C), superabsorbent application use (S) and interaction between cultivar, depth and SAP in cultivar and depth at $1 \%$ level on the number of days up to $50 \%$ germination (Table 2). The results showed that number of days up to $50 \%$ germination was significantly affected by years (Table 3 ). 
Table 2. The analysis of compound variance for the effect of cultivar, sowing depth, and superabsorbent use on some potato traits

\begin{tabular}{|c|c|c|c|c|c|c|c|}
\hline Change sources & Df & $\begin{array}{l}\text { Number of } \\
\text { days to } \\
\text { germination }\end{array}$ & $\begin{array}{l}\text { Number } \\
\text { of stems } \\
\text { per crop }\end{array}$ & $\begin{array}{c}\text { Stem } \\
\text { diameter at } \\
\text { flowering } \\
\text { time }\end{array}$ & $\begin{array}{c}\text { Crop } \\
\text { height at } \\
\text { flowering } \\
\text { time }\end{array}$ & $\begin{array}{l}\text { Tuber } \\
\text { yield }\end{array}$ & $\begin{array}{c}\text { Tuber dry } \\
\text { matter }\end{array}$ \\
\hline Year $(Y)$ & 1 & $286.17 * *$ & $3.60 * *$ & $2.097 * *$ & $200.88^{* *}$ & $10.39 * *$ & $197.0407 * *$ \\
\hline Repetition(R)(Y) & 4 & 24.49 & 0.04 & 0.021 & 12.10 & 0.18 & 4.7807 \\
\hline Depth (D) & 3 & $98.71 * *$ & $0.62 * *$ & $0.309 * *$ & $46.72 * *$ & $49.90 * *$ & $116.3769 * *$ \\
\hline $\mathrm{Y} * \mathrm{D}$ & 3 & $0.11 \mathrm{~ns}$ & $0.01 \mathrm{~ns}$ & $0.009 \mathrm{~ns}$ & $0.06 \mathrm{~ns}$ & Ons & $0.0002 \mathrm{~ns}$ \\
\hline $\mathrm{R} * \mathrm{D}(\mathrm{Y})$ & 12 & 19.70 & 0.03 & 0.005 & 5.24 & 0.41 & 1.0554 \\
\hline Cultivar (C) & 2 & $1265.81 * *$ & $36.41 * *$ & $0.179 * *$ & $3454.51 * *$ & $8.17 * *$ & $40.4527 * *$ \\
\hline $\mathrm{D} * \mathrm{C}$ & 6 & $42.12 * *$ & $0.04 \mathrm{~ns}$ & $0.222 * *$ & $68.31 * *$ & $9.79 * *$ & $7.7951 * *$ \\
\hline $\mathrm{Y} * \mathrm{C}$ & 2 & $0.21 \mathrm{~ns}$ & $0.02 \mathrm{~ns}$ & $0.004 \mathrm{~ns}$ & $1.91 \mathrm{~ns}$ & Ons & $0.0001 \mathrm{~ns}$ \\
\hline $\mathrm{Y} * \mathrm{D} * \mathrm{C}$ & 6 & $1.32 \mathrm{~ns}$ & $0.06 \mathrm{~ns}$ & $0.003 \mathrm{~ns}$ & $0.32 \mathrm{~ns}$ & Ons & $0.0001 \mathrm{~ns}$ \\
\hline $\mathrm{R} * \mathrm{D} * \mathrm{C}(\mathrm{Y})$ & 32 & 17.79 & 0.06 & 0.003 & 2.99 & 0.28 & 1.6067 \\
\hline Superabsorbent(S) & 1 & $91.84 * *$ & $1.28 * *$ & $0.700 * *$ & $309.58 * *$ & $35.44 * *$ & $313.7075 * *$ \\
\hline $\mathrm{Y}^{*} \mathrm{~S}$ & 1 & $0.17 \mathrm{~ns}$ & $0.02 \mathrm{~ns}$ & $0.002 \mathrm{~ns}$ & $1.18 \mathrm{~ns}$ & Ons & $0.0016 \mathrm{~ns}$ \\
\hline $\mathrm{D} * \mathrm{~S}$ & 3 & $23.85 \mathrm{~ns}$ & $0.08 \mathrm{~ns}$ & $0.047 * *$ & $15.86^{* *}$ & $1.04 *$ & $3.6122 \mathrm{~ns}$ \\
\hline $\mathrm{Y} * \mathrm{D} * \mathrm{~S}$ & 3 & $0.34 \mathrm{~ns}$ & $0.09 \mathrm{~ns}$ & $0.002 \mathrm{~ns}$ & $0.43 \mathrm{~ns}$ & Ons & $0.0002 \mathrm{~ns}$ \\
\hline $\mathrm{C} * \mathrm{~S}$ & 2 & $21.34 \mathrm{~ns}$ & $0.19 *$ & $0.021 * *$ & $14.89 *$ & $0.47 \mathrm{~ns}$ & $2.4021 \mathrm{~ns}$ \\
\hline $\mathrm{Y}^{*} \mathrm{C}^{*} \mathrm{~S}$ & 2 & $0.88 \mathrm{~ns}$ & $0.06 \mathrm{~ns}$ & $0.005 \mathrm{~ns}$ & $0.39 \mathrm{~ns}$ & Ons & $0.0001 \mathrm{~ns}$ \\
\hline $\mathrm{D} * \mathrm{C} * \mathrm{~S}$ & 6 & $24.30 * *$ & $0.08 \mathrm{~ns}$ & $0.04 * *$ & $19.26^{* *}$ & $1.24 * *$ & $8.9846 * *$ \\
\hline $\mathrm{Y}^{*} \mathrm{D} * \mathrm{C} * \mathrm{~S}$ & 6 & $0.82 \mathrm{~ns}$ & $0.02 \mathrm{~ns}$ & $0.003 \mathrm{~ns}$ & $1.19 \mathrm{~ns}$ & Ons & $0.0001 \mathrm{~ns}$ \\
\hline Error & 48 & 6.09 & 0.04 & 0.003 & 2.35 & 0.31 & 1.7108 \\
\hline c.v & - & 10.58 & 4.63 & 4.52 & 4.66 & 8.05 & 6.64 \\
\hline
\end{tabular}

ns, *, and **: insignificant and significant at levels of $5 \%$ and $1 \%$, respectively

Table 3. The effect of years on evaluated parameters in potato plant

\begin{tabular}{c|c|c|c|c|c|c}
\hline Years & $\begin{array}{c}\text { Number of } \\
\text { days to } \\
\text { germination }\end{array}$ & $\begin{array}{c}\text { Number of } \\
\text { stems per } \\
\text { crop }\end{array}$ & $\begin{array}{c}\text { Stem diameter } \\
\text { at flowering } \\
\text { time }(\mathbf{c m})\end{array}$ & $\begin{array}{c}\text { Crop height at } \\
\text { flowering time } \\
(\mathbf{c m})\end{array}$ & $\begin{array}{c}\text { Tuber yield } \\
\left(\mathbf{k g} / \mathbf{m}^{2}\right)\end{array}$ & $\begin{array}{c}\text { Tuber dry } \\
\text { matter } \\
(\%)\end{array}$ \\
\hline $2015-016$ & $154^{\mathrm{b}}$ & $4.54^{\mathrm{b}}$ & $1.15^{\mathrm{b}}$ & $31^{\mathrm{b}}$ & $6.69^{\mathrm{b}}$ & $18^{\mathrm{b}}$ \\
$2016-017$ & $157^{\mathrm{a}}$ & $4.86^{\mathrm{a}}$ & $1.39^{\mathrm{a}}$ & $34^{\mathrm{a}}$ & $7.23^{\mathrm{a}}$ & $20^{\mathrm{a}}$ \\
\hline
\end{tabular}

Values with the different letters are significantly different according to Duncan's multiple range test at $\mathrm{P}<0.05$

\section{Crop height}

Effect of year (Y), sowing depth (D), cultivar (C), superabsorbent use (S), and mutual effects of sowing depth and SAP, cultivar and sowing depth and interaction effect of sowing depth, cultivar and SAP at $1 \%$ level and interaction effect of cultivar and SAP was significant at crop height $(\mathrm{p}<0.05)($ Table 2).

\section{Stem diameter}

The results of compound analysis showed that stem diameter under the effect of year (Y), sowing depth (D), cultivar (C), superabsorbent use application (S) and interaction 
of sowing depth and SAP, cultivar and sowing depth, cultivar and SAP and interactions of sowing depth, cultivar and SAP were at $1 \%$ level (Table 2).

\section{The number of stems per crop}

The results of variance analysis showed the significant effect of year (Y), sowing depth (D), cultivar (C), use of super adsorbent (S) at $1 \%$ level, and interaction of cultivar and SAP on the number of stems per crop at 5\% level (Table 2).

\section{Tuber yield}

The results of compound analysis showed the significant effect of year (Y), sowing depth (D), cultivar (C), use of super adsorbent (S) and interaction of sowing depth and cultivar and SAP, cultivar and sowing depth at $1 \%$ and interaction between SAP and sowing depth at $5 \%$ level on the tuber yield (Table 2). The results showed that tuber yield was significantly affected by years (Table 3 ).

\section{Percentage of dry matter}

The results of compound analysis showed that the dry matter percentage of the tuber was significantly $(\mathrm{P}<0.01)$ affected by year $(\mathrm{Y})$, sowing depth $(\mathrm{D})$, cultivar $(\mathrm{C})$, and superabsorbent use (S). Meanwhile, the interaction effect of cultivar and sowing depth as well as the interaction effect of sowing depth, cultivar and SAP were significant at $1 \%$ level (Table 2).

\section{Discussion}

\section{The number of days up to $50 \%$ germination}

The results of comparing the three-sided interaction between sowing depth, cultivar and SAP showed that the maximum number of days to $50 \%$ germination in Agria cultivar was obtained with a depth of $25 \mathrm{~cm}$ with a SAP use (165 days). The use of SAP with sowing depths of 10,15 and $25 \mathrm{~cm}$ resulted in significant increase of days to $50 \%$ germination in Agria cultivar while this situation did not occur in two other cultivars (Fig. 2). It should be noted that the survival rate of tubers and their germination percentage were insignificant at $10 \mathrm{~cm}$ depth of all cultivars especially Agria cultivar due the frozen tubers.

\section{Crop height}

The results of mean comparison showed that the highest crop height in Agria cultivar was obtained at a depth of $15 \mathrm{~cm}$ with a SAP use $(46 \mathrm{~cm})$, which increased $9.5 \%$ than the use of SAP at the same depth and cultivar (Agria). In general, the use of SAP in all three cultivars resulted in a significant increase in crop height relative to non-use of SAP (Fig. 3).

The decrease in stem height with water deficit during the growing season and in the absence of SAP use is consistent with the results of research by Motalebifard et al. (2014). Cell growth is the most sensitive stage under the influence of water stress. The size of organs is limited by decreasing cell growth and the first palpable effect due to water deficiency in the crops is shown by decreasing leaf size and crop height (Kirank et al., 2003). The results of studies by Jahan et al. (2013) and Islam et al. (2011) showed 
the positive effect of SAP on crop height which is consistent with the results of this research.

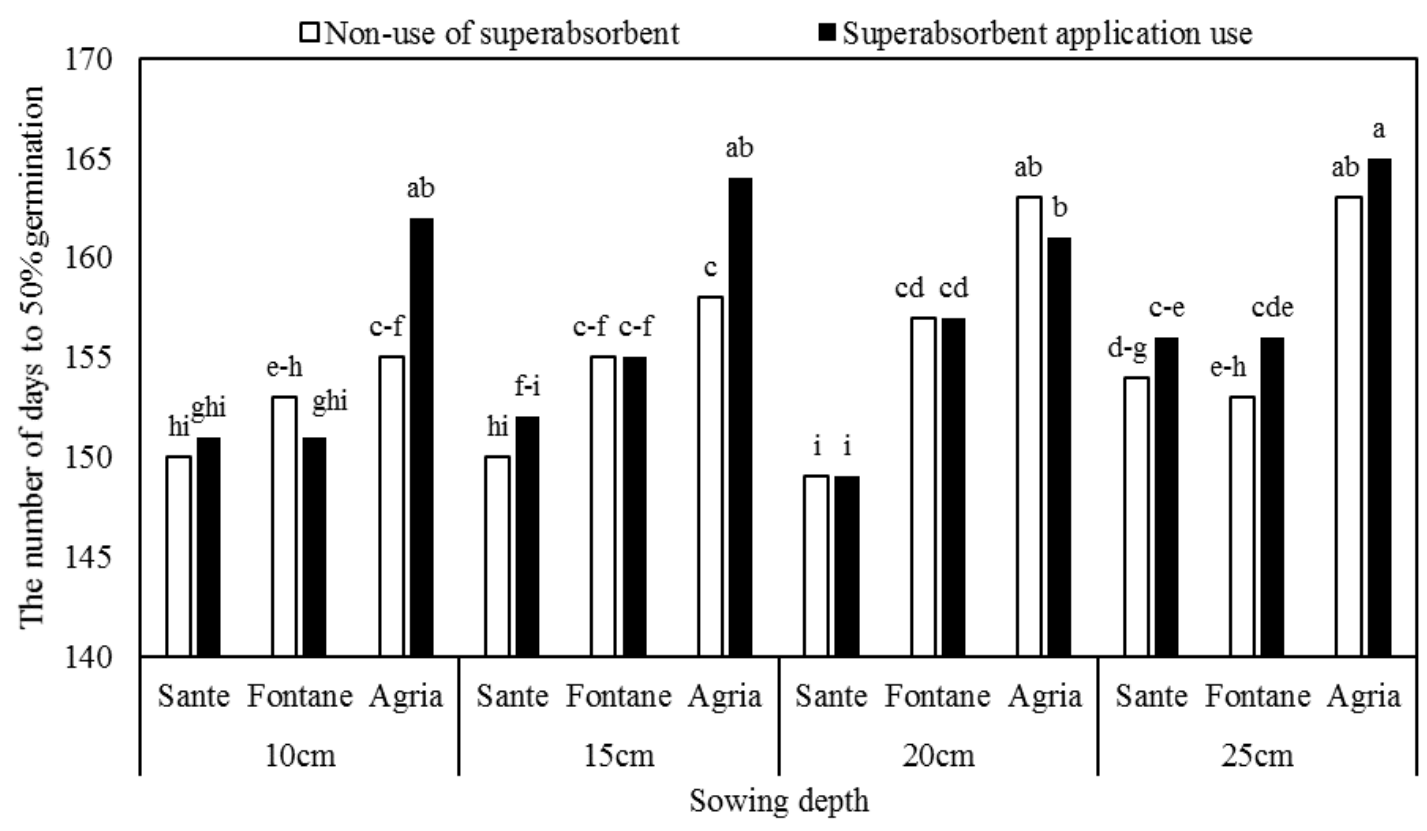

Figure 2. The interaction of cultivar (Sante, Fontane and Agria), sowing depth (10, 15, 20 and $25 \mathrm{~cm}$ ), and superabsorbent (application and non-application) on the number of days to 50\% germination in potato. At each treatment, values with the different letters are significantly different according to Duncan's multiple range test at $P<0.05$

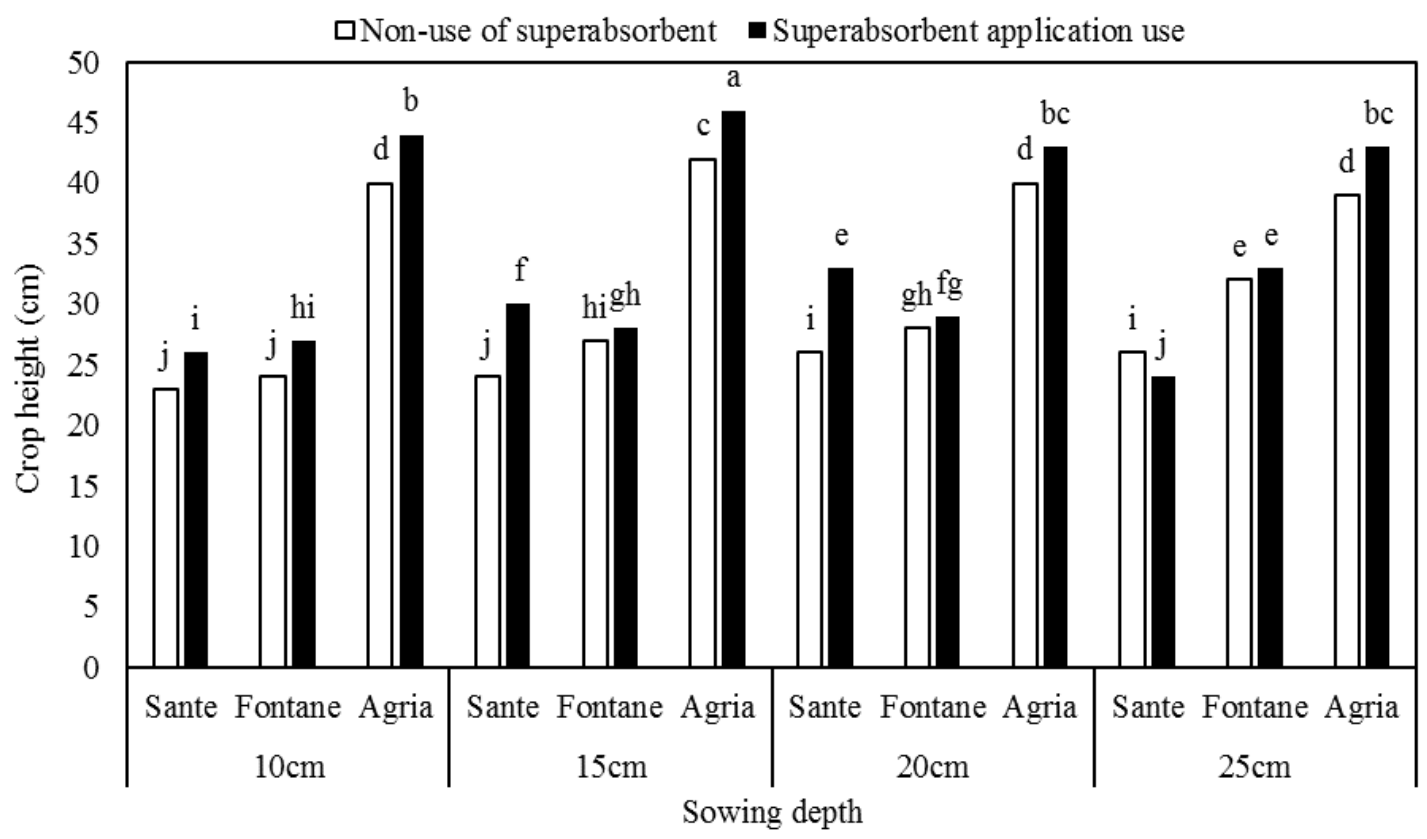

Figure 3. The interaction of cultivar (Sante, Fontane and Agria), sowing depth (10, 15, 20 and $25 \mathrm{~cm}$ ), and superabsorbent (application and non-application) on crop height of potato at flowering time. At each treatment, values with the different letters are significantly different according to Duncan's multiple range test at $P<0.05$ 


\section{Stem diameter}

With the significance of the interaction of sowing depth, cultivar and SAP, it was found that the highest stem diameter was Sante cultivar at a depth of $10 \mathrm{~cm}$ with the use of SAP $(1.55 \mathrm{~cm})$ and Agria cultivar at a depth of $20 \mathrm{Cm}$ with the use of SAP $(1.57 \mathrm{~cm})$. In general, the use of SAP in all three cultivars resulted in a significant increase in stem diameter (Fig. 4).

\section{The number of stems per crop}

The significance of interaction between cultivars and SAP showed that in Sante and Agria, the use of SAP resulted in a significant increase in number of stems per crop. However, the use of SAP had no significant effect on number of stems per crop in Fontane cultivar (Fig. 5).

\section{Tuber yield}

The highest tuber yield was in the Fontane cultivar at a depth of $25 \mathrm{~cm}$ with SAP use. In general, the use of SAP in all three cultivars and different sowing depths resulted in a significant increase in tuber yield relative to non-use of SAP (Fig. 6). In this regard, the potato yield under the sowing depth (greater than $20 \mathrm{~cm}$ depending on the sowing conditions) was increased (Ezekiel, 1992). The results of Esehaghbeygi's study (2010) indicated that cultivar and sowing depth had a significant effect on the yield of potato and dry matter.

Extreme leaf area reduction of radiation absorption, as well as the reduction of photosynthetic yields result in the loss of dry matter and yield under drought stress conditions.

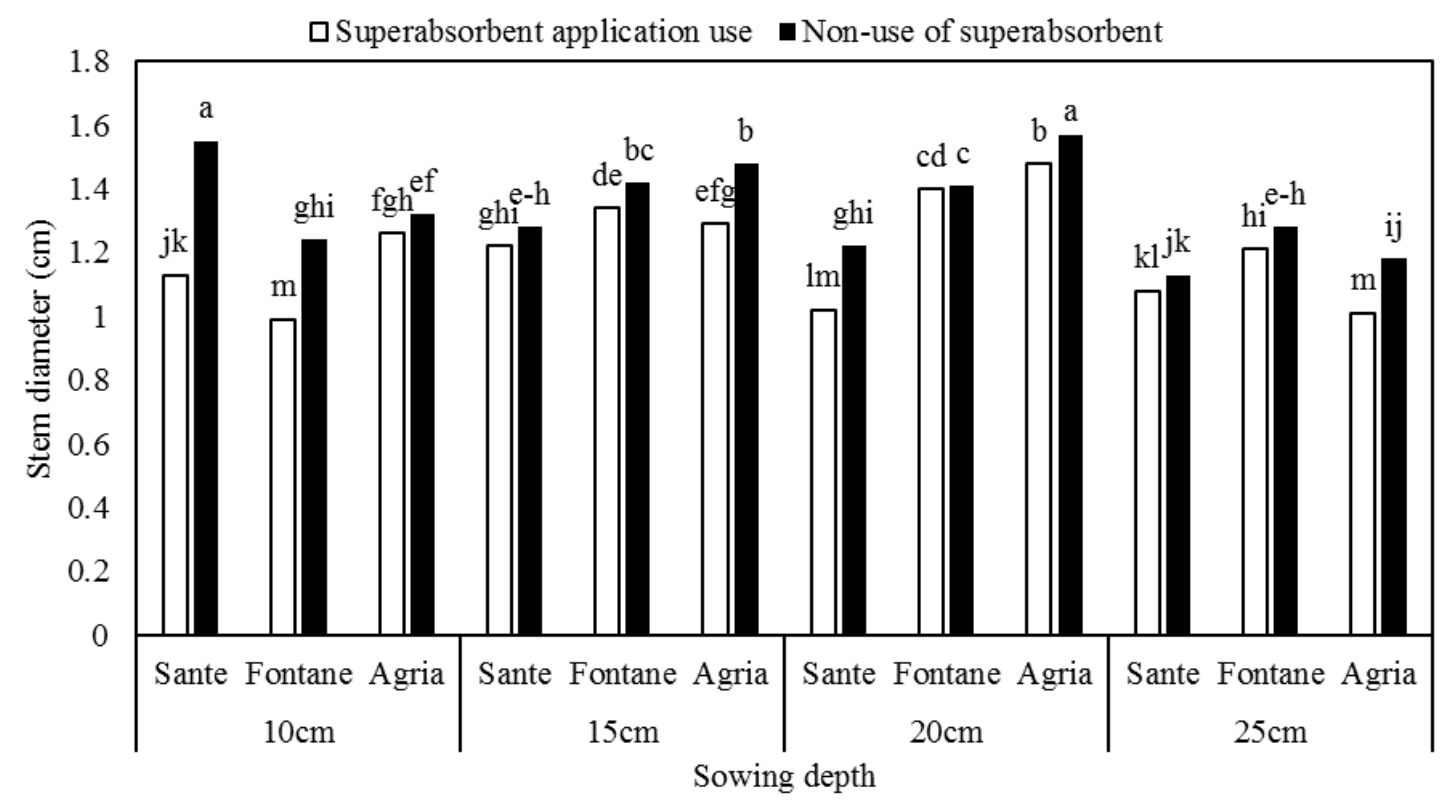

Figure 4. The interaction of cultivar (Sante, Fontane and Agria), sowing depth (10, 15, 20 and $25 \mathrm{~cm}$ ), and superabsorbent (application and non-application) on stem diameter of potato at flowering time. At each treatment, values with the different letters are significantly different according to Duncan's multiple range test at $P<0.05$ 


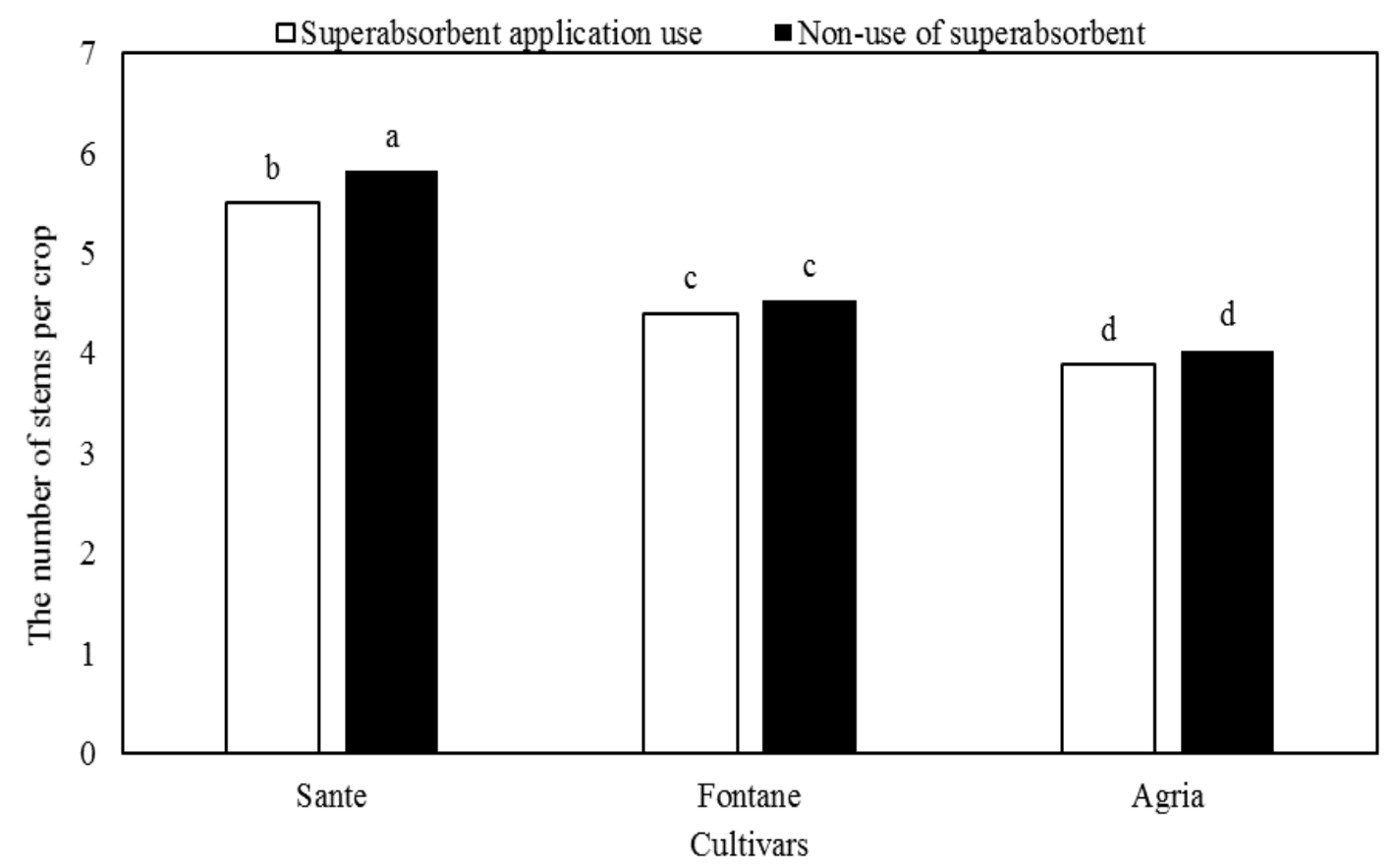

Figure 5. The interaction of cultivar (Sante, Fontane and Agria) and superabsorbent (application and non-application) on the number of stems in potato at flowering time. At each treatment, values with the different letters are significantly different according to Duncan's multiple range test at $P<0.05$

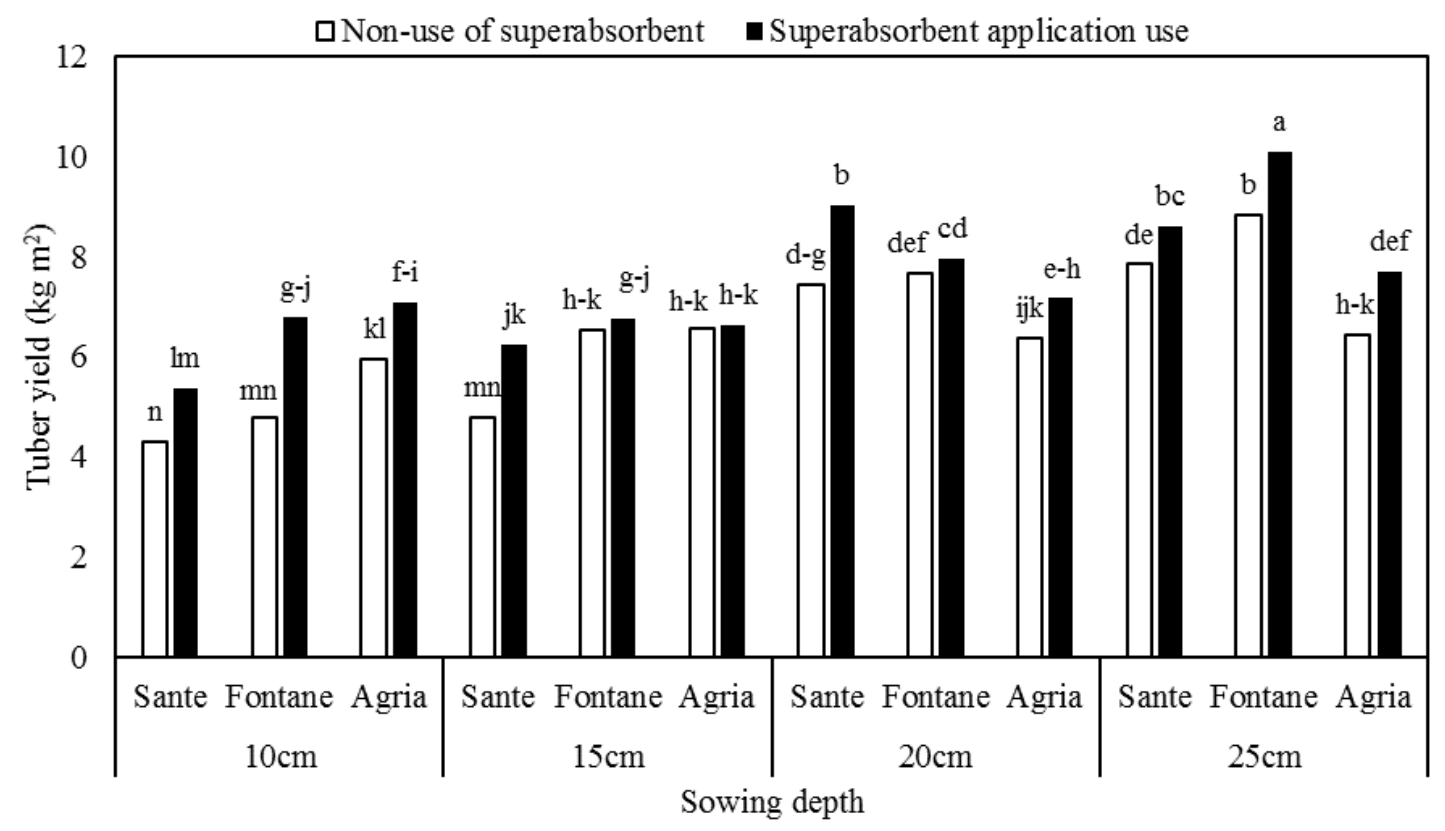

Figure 6. The interaction of cultivar (Sante, Fontane and Agria), sowing depth (10, 15, 20 and $25 \mathrm{~cm}$ ), and superabsorbent (application and non-application) on potato tuber yield. At each treatment, values with the different letters are significantly different according to Duncan's multiple range test at $P<0.05$ 
In this relation, King et al. (2004) stated that the soil water deficit in the mid and late stages of potato tuber yield could reduce the tuber yield. SAP can increase the growth and yield of crops by increasing the absorption and maintenance of water in soil, storage of nitrogen, phosphorus, sulfur and exchangeable cations, as well as increasing ventilation by improving soil structure (Nazarli et al., 2010). Other researchers reported a decrease in yield, yield components including number of tubers per crop, and the average weight of the tuber per crop, as well as reduced water use efficiency due to the application of water stresses (Alva et al., 2012; Liu et al., 2006; Ayas, 2013).

\section{Percentage of dry matter}

With significance of interaction between cultivar, sowing depth, use of SAP, it was determined that the highest percentage of dry matter in Sante and Fontane cultivars was cultured at $10 \mathrm{~cm}$ depth without using SAP. In general, the use of SAP and increasing the sowing depth in all three cultivars resulted in a significant decrease in the percentage of dry matter, while their variation was not uniform (Fig. 7).

Several studies showed that the percentage of dry matter of the tubers increases with decreasing irrigation, drought stress, and reducing yield (Ayas and Korukcu, 2010; Ayas, 2013; Porter et al., 1999). It seems that the reason for increasing dry matter percentage due to drought stress is to reduce the potential of water around the root and water deficit of the crop resulting in less water being directed to the tissues of the crop while the percentage of dry matter of the tubers increased (Bagheri et al., 2016).

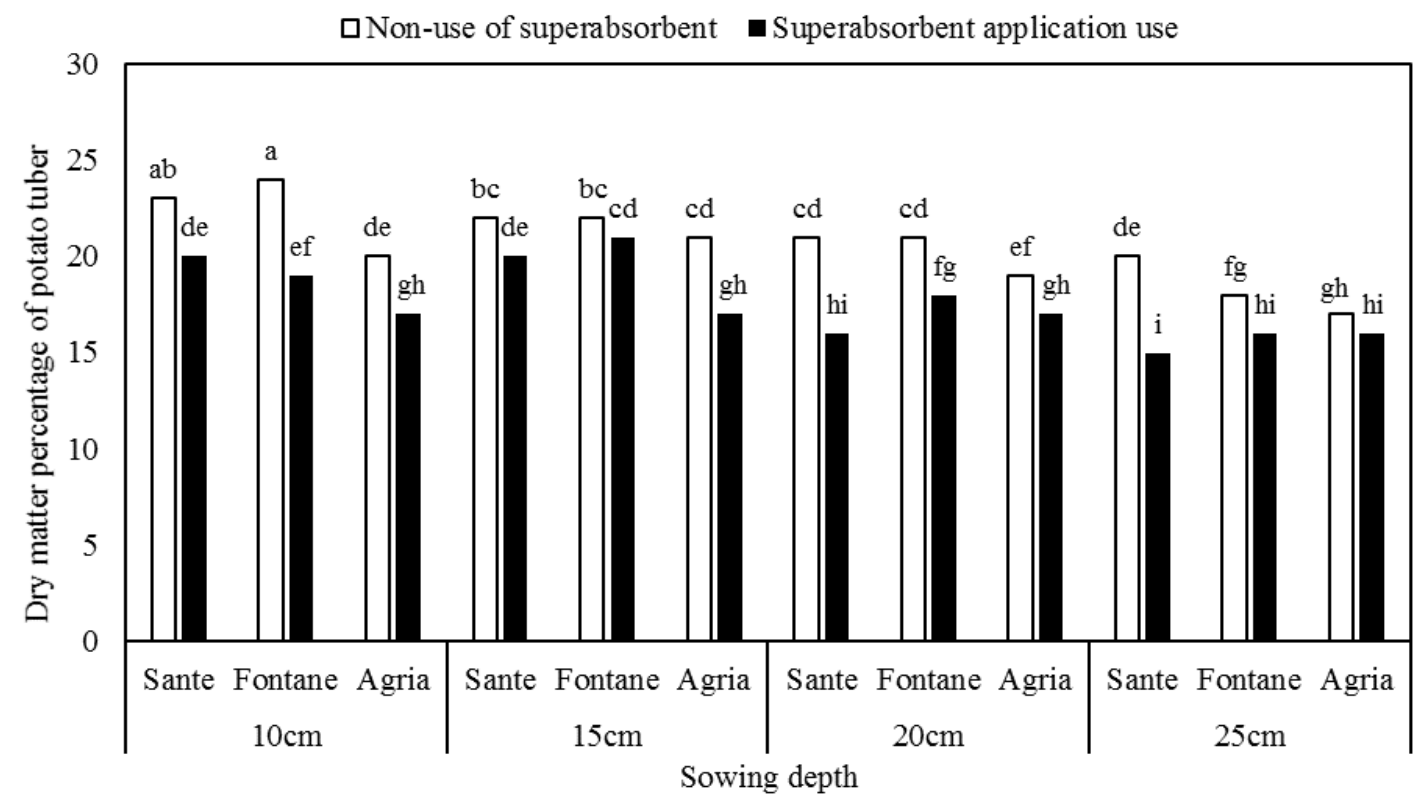

Figure 7. The interaction of cultivar (Sante, Fontane and Agria), sowing depth (10, 15, 20 and $25 \mathrm{~cm}$ ), and superabsorbent (application and non-application) on dry matter percentage of potato tuber. At each treatment, values with the different letters are significantly different according to Duncan's multiple range test at $P<0.05$

\section{Leaf area index (LAI) and leaf area duration (LAD)}

The results showed that in all three cultivars, the use of SAP led to an increase in leaf area index and leaf area duration. The highest leaf area index in Sante and Agria 
cultivars was obtained with SAP use (Figs. 8 and 9). In Sante cultivar at $10 \mathrm{~cm}$ depth, leaf area index and leaf area duration were lower than other treatments. Increasing the sowing depth to $20 \mathrm{~cm}$ in Sante cultivar resulted in an increase in leaf area index. In other treatments, this trend was the same (Figs. 10 and 11). LAI and LAD levels increased with increasing SAP depth and use. The highest rate of these two traits was obtained under the conditions of SAP use at three depths of 15,20 , and $25 \mathrm{~cm}$. The amount of $L A I$ and $L A D$ at sowing depth of $10 \mathrm{~cm}$ was less than three other depths (Figs. 12 and 13).

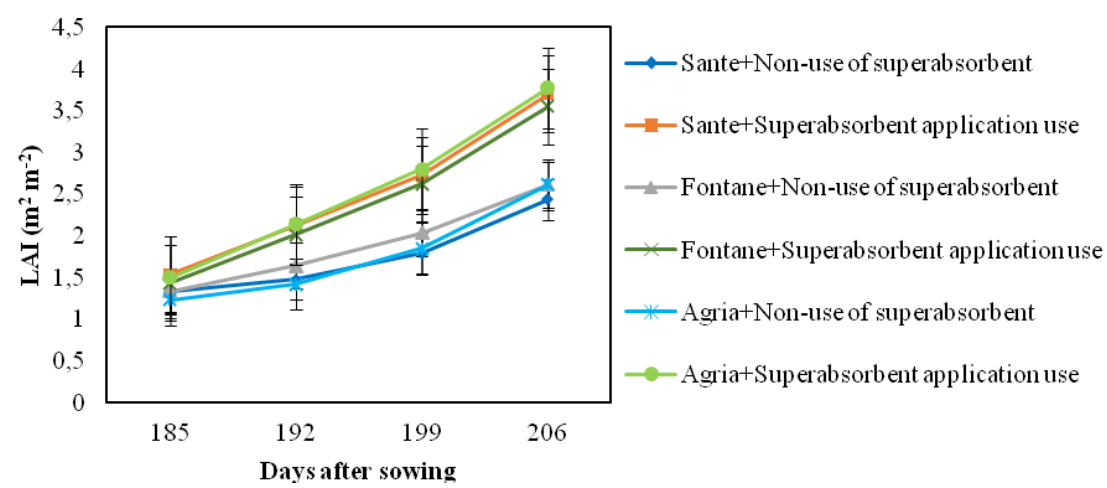

Figure 8. The effects of cultivar and superabsorbent use on the leaf area index of potato (LAI). Bars represent standard errors of three replicate

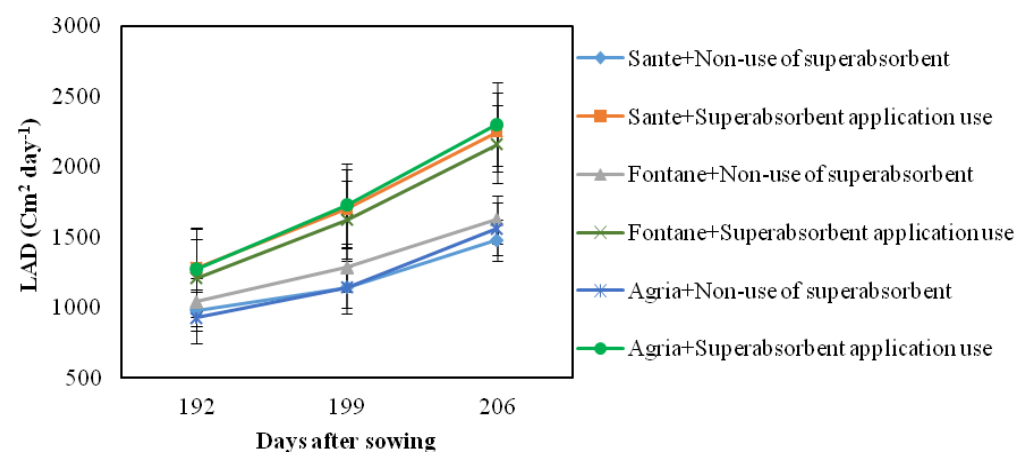

Figure 9. The effects of cultivar and superabsorbent use on the leaf area duration of potato (LAD). Bars represent standard errors of three replicate

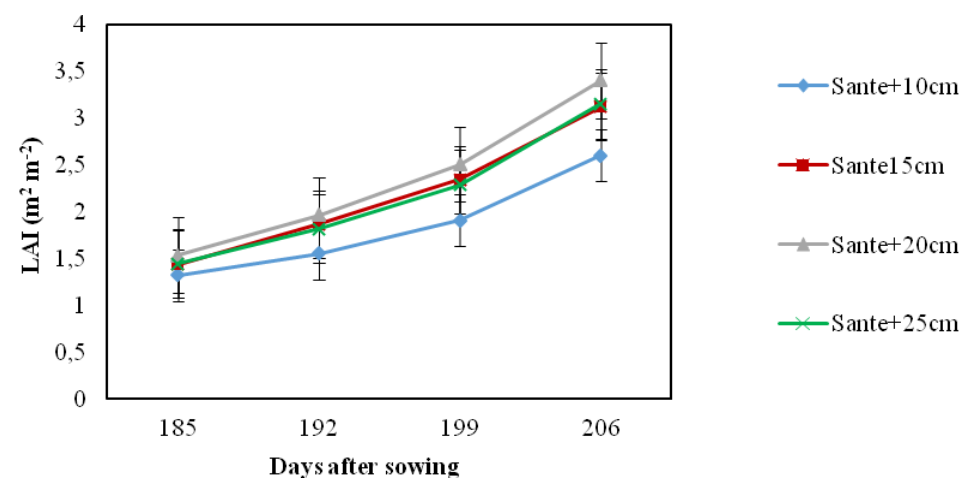

Figure 10. The effects of sowing depth on the leaf area index of potato (LAI). Bars represent standard errors of three replicate 

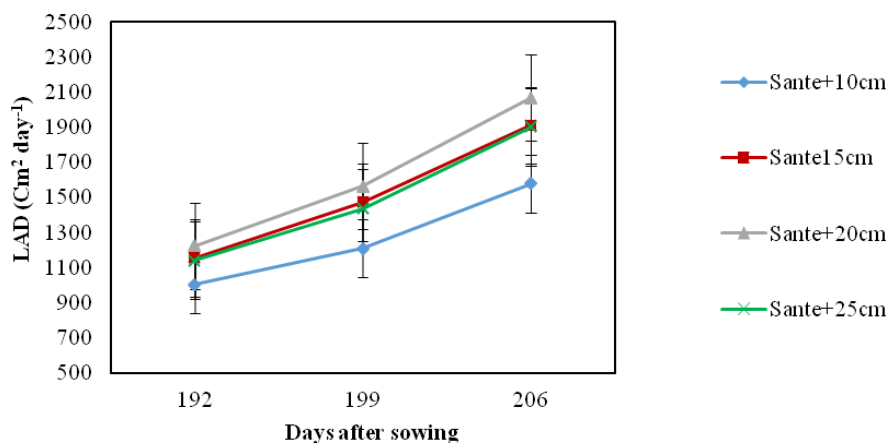

$\rightarrow-S a n t e 15 \mathrm{~cm}$

- Sante $20 \mathrm{~cm}$

$\longrightarrow$ Sante $+25 \mathrm{~cm}$

Days after sowing

Figure 11. The effects of sowing depth on the leaf area duration of potato (LAD). Bars represent standard errors of three replicate

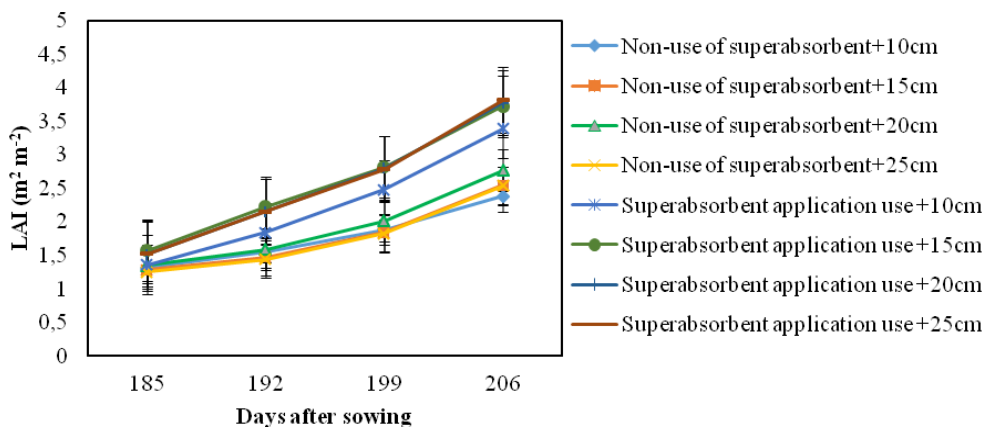

Figure 12. The effects of superabsorbent use and sowing depth on the leaf area index of potato (LAI). Bars represent standard errors of three replicate
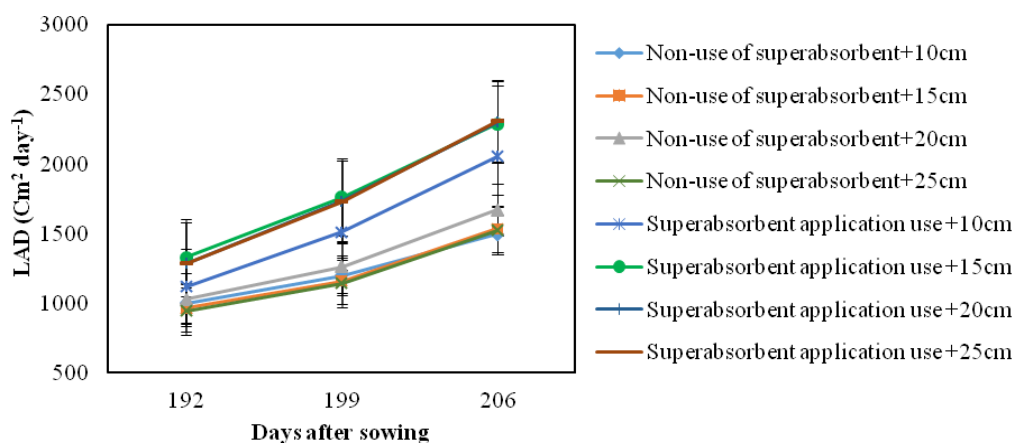

Figure 13. The effects of superabsorbent use and sowing depth on the leaf area duration of potato (LAD). Bars represent standard errors of three replicate

Drought stress can reduce leaf area and photosynthesis (Ierna and Mauromicale, 2006). The study results of FazeliRostampour (2013) showed that the use of SAP and supply of needed water up to $80 \%$ increased the leaf area index and leaf area duration.

\section{Crop growth rate (CGR)}

The effects of cultivar and SAP use indicated that in all three cultivars, the use of superabsorbent $\mathrm{n}$ led to an increase in CGR (Fig. 14). In Sante cultivar at $10 \mathrm{~cm}$ depth, 


$$
-7075 \text { - }
$$

$C G R$ was less than other treatments during the growing season. Increasing the depth of cultivation in the Sante cultivar led to an increase in CGR (Fig. 15). In each of the four depths, the SAP use resulted in an increase in $C G R$ compared with the absence of SAP use. The highest $C G R$ was obtained under the conditions of SAP use at three depths of 15, 20 and $25 \mathrm{~cm}$ (Fig. 16).

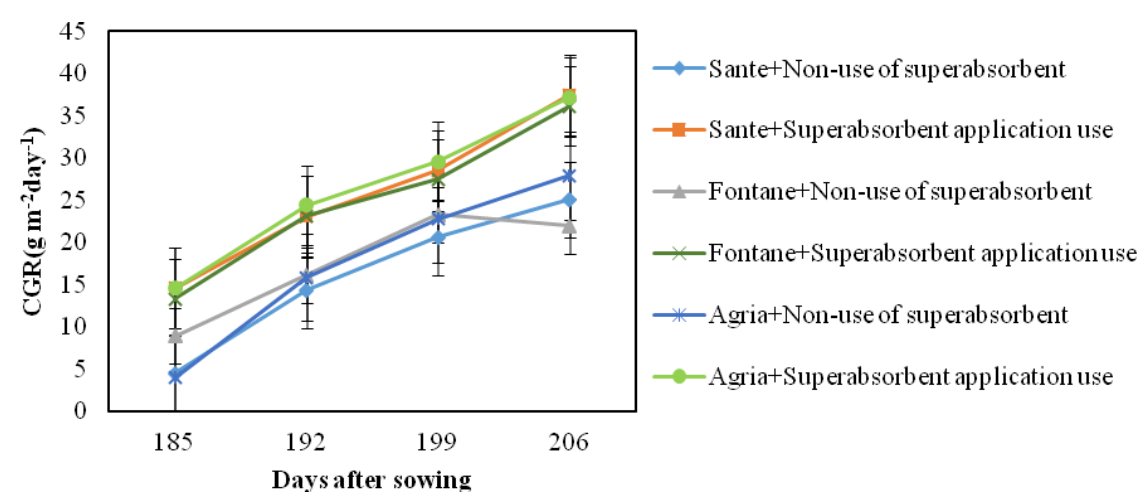

Figure 14. The effect of cultivar and superabsorbent use on potato growth rate (CGR). Bars represent standard errors of three replicate

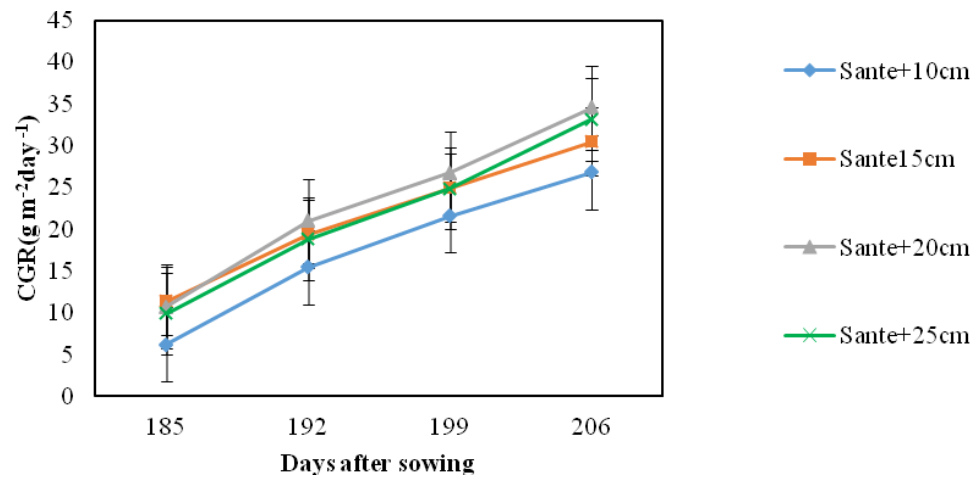

Figure 15. The effect of cultivar and sowing depth on potato growth rate (CGR). Bars represent standard errors of three replicate

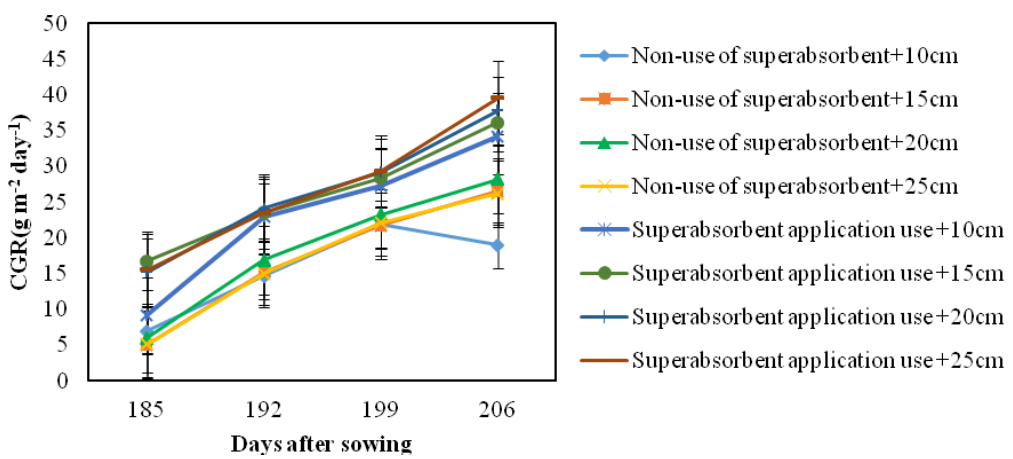

Figure 16. The effect of superabsorbent use and sowing depth on crop growth rate (CGR). Bars represent standard errors of three replicate 
Higher the LAI and the adequate absorption of radiation results in higher production rates and higher growth rates. Reducing the leaf water potential results in the reduced growth rate of the product due to the increase in respiration rate associated with the increase in plant temperature and reduction of the intensity of photosynthesis (Evans, 1978).

\section{Conclusion}

In conclusion, increasing the sowing depth to $25 \mathrm{~cm}$ resulted in increasing the number of days to $50 \%$ germination, number of stems per crop, and tuber yield. However, increasing the sowing depth resulted in the reduced tuber dry weight. In general, the use of superabsorbent in all three cultivars and at different sowing depths resulted in a significant increase in tuber yield relative to the non-use of superabsorbent. The results of growth indices showed that in all three cultivars, the use of superabsorbent led to an increase in leaf area index, in leaf area duration, and in crop growth rate. Based on the results of this study and durability of superabsorbent polymer in soil, we can say that using superabsorbent under different sowing depth conditions can increase the potato yield and productivity.

\section{REFERENCES}

[1] Acquaah, G. (2005): Principles of Crop Production: Theory, Techniques, and Technology. Second edition. - Pearson Prentice Hall, New Jersey, USA.

[2] Alva, A. K., Ren, H., Moore, A. D. (2012): Water and nitrogen management effects on biomass accumulation and partitioning in two potato cultivars. - American Journal of plant Sciences 3(1): 164-170.

[3] Arab, H. R., Afshari, H., Samdaliri, M., Laei, GH., Toudar, S. R. (2011): The effect of planting date, depth and density on yield and yield components of potato in Shahrood (Iran). - Journal of Research in Agricultural Science 7(2): 141-149.

[4] Ayas, S. (2013): The effects of different regimes on potato (Solonum tuberosum L. Hermes) yield and quality characteristics under unheated greenhouse conditions. Bulgarian Journal of Agricultural Science 19(1): 87-95.

[5] Ayas, S., Korukcu, A. (2010): Water-yield relationships in deficit irrigated potato. Journal of Agricultural Factulty of Uludag University 24(2): 23-26.

[6] Bagheri, H. R., Qarineh, M. H., Bakhshande, A. S., Tayyi, J., Mehnatkesh, A. S., Andrzian, B. (2016): Effects of water deficit and different nitrogen fertilizer levels on yield, yield components and water use efficiency of potato (Solanum tuberosum L.). Environmental Stresses in Crop Science 9(1): 1-14.

[7] Bannayan, M., Sanjani, S., Alizadeh, A., Lotfabadi, S., Mohammadian, A. (2010): Association between climate indices, aridity index, and rainfed crop yield in northeast of Iran. - Field Crops Research 118(2): 105-114.

[8] Esehaghbeygi, A. (2010): The effect of cultivation depth and variety on the yield and properties of potato tuber. - Journal of Plant Productions 33(1): 67-74.

[9] Evans, L. T. (1978): Crop Physiology: Some Case Histories. First edition. - Cambridge University Press, Cambridge, UK.

[10] Ezekiel, R., Bhargava, S. C. (1992): Nitrogen distribution within the potato plant in relation to planting date under short day conditions. - Indian Journal of Plant Physiology 35(2): 130-139. 
[11] FazeliRostampour, M. (2013): Effects of irrigation regimes and polymer on dry matter yield and several physiological traits of forage sorghum var 'Speedfeed'. - African Journal of Biotechnology 12(51): 7074-7080.

[12] FAO (2008): FAOSTAT. Statistic Database. - http://faostat.fao.org/.

[13] FAO (2013): FAOSTAT. Statistic Database. - http://faostat.fao.org/.

[14] Garg, B., Lata, C., Prasad, M. (2012): A study of the role of gene TaMYB2 and an associated SNP in dehydration tolerance in common wheat. - Molecular Biology Reports 39(12): 10865-10871.

[15] Ghooshchi, F. (2015): Investigation the possibility of decreasing the damage due to irrigation-cut tension on physiological characteristics and corn quality by applying the super absorbent polymer. - Crop Physiology Journal 7(27): 85-94.

[16] Haase, T., Schuler, C., Heb, J. (2007): The effects of different N and K sources on tuber nutrient uptake, total graded yield of potatoes (Solanum tuberosum L.) for processing. Agronomy Journal 26(3): 187-193.

[17] Hassanpanah, D. (2016): The most suitable of cultivars and planting depth for potato autumn sowing in various regions of Ardabil province. - Ardabil Agricultural Extension Coordination Management 115: 1-16.

[18] He, X. S., Zhang, F. D. (2005): Characteristics and performance of water-absorbent polymer coated urea. - Plant Nutrition and Fertilizer Science 12(3): 334-339.

[19] Ierna, A., Mauromicale, G. (2006): Physiological and growth response to moderate water deficit of off-season potatoes in a Mediterranean environment. - Agricultural Water Management 82(1-2): 193-209.

[20] Islam, M. R., Xue, X., Mao, S., Zhao, X., Eneji, A. E., Hu, Y. (2011): Superabsorbent polymers (SAP) enhance efficient and eco-friendly production of corn (Zea mays L.) in drought affected areas of northern china. - African Journal of Biotechnology 10(24): 4887-4894.

[21] Jahan, M., Kamayestani, N., Ranjbar, F. (2013): Assay for applying super absorbent polymer in a low input corn (Zea mays L.) production system aimed to reduce drought stress under Mashhad conditions. - Agroecology 5(3): 272-281.

[22] King, B. A., Stark, G. C., Love, S. (2004): Potato Production with Limited Water Supplies. - Agricultural Experiment Station Publications, University of Idaho, United States of America, pp. 1-8.

[23] Kirnak, H., Gencoglan, C., Degirmenci, V. (2003): Effect of deficit irrigation on yield and growth of second crop corn in Harran Plain conditions. - Journal of Agricultural Faculty of Ataturk University 34(2): 117-123.

[24] Liu, F., Shahnazari, A., Anderson, M. N., Jacobsen, S. E., Jensen, Ch. R. (2006): Effects of deficit irrigation (DI) and partial root drying (PRD) on gas exchange, biomass partitioning, and water use efficiency in potato. - Scientia Horticulturae 109(2): 113-117.

[25] Maksup, S., Roytrakul, S., Supaibulwatana, k. (2014): Physiological and comparative proteomic analyses of Thai jasmine rice and two check cultivars in response to drought stress. - Journal of Plant Interactions 9(1): 43-55.

[26] Motalebifard, R., Najafi, N., Oustan, Sh., Nayshabori, M. R., Valizadeh, M. (2014): Effect of soil moisture, phosphorus and zinc levels on the growth attributes of potato, greenhouse conditions. - Iranian Journal of Soil and Water Research 45(1): 75-86.

[27] Nazarli, H., Zardashti, M. R., Darvishzadeh, R., Najafi, S. (2010): The effect of water stress and polymer on water use efficiency, yield and several morphological traits of sunflower under greenhouse condition. - Notulae Scientia Biologicae 2(4): 53-58.

[28] Parvizi, K. (2008): Evaluation of quantitative and qualitative traits of late and early ripening advanced potato cultivars. - Pajouhesh \& Sazandegi 21(2): 80-90.

[29] Parvizi, K., GhadamiFiroozabadi, A. (2015): Evaluation the effect of water deficit methods on quantitative and qualitative traits of new potato cultivar. - Iranian Journal of Field Crops Research 13(3): 637-650. 
[30] Porter, G. A., Opena, G. B., Bradbury, W. B., McBurnie, J. C., Sisson, J. A. (1999): Soil management and supplemental irrigation effects on potato: I. Soil properties, tuber yield, and quality. - Agronomy Journal 91(3): 416-425.

[31] Rashidi, N., Arji, A., Gardkane, M., Kashi, A. (2015): Effect of organic and superabsorbent cultures on physiological and biochemical properties of potato cultivars 'Marfona' in Kermanshah. - Journal of Horticultural Science 28(4): 453-463.

[32] Shock, C. C., Shock, B. M., Welch, T. (2013): Strategies for efficient irrigation water use. - Oregon State University, Sustainable Agriculture Techniques EM8783: 1-7.

[33] Sirousmehr, A., Arabi, J., Asgharipour, M. R. (2014): Effect of drought stress levels and organic manures on yield, essential oil content and some morphological characteristics of sweet basil (Ocimum basilicum). - Advances in Environmental Biology 8(4): 880-885.

[34] Taiz, L., Zeiger, E. (2006): Plant Physiology. Fourth edition. - Sinauer Associates, Sunderland, Massachusetts, USA.

[35] Yazdani, F., Allahdadi, I., Akbari, G. A., Behbahani, M. R. (2007): Effect of different rates of superabsorbent polymer (Tarawat A200) on soybean yield and yield components (Glycine max L.). - Pajouhesh \& Sazandegi 20(2): 167-174. 